\title{
Early Childhood Caries: Prevalence, Risk Factors, and Prevention
}

\author{
Sukumaran Anil ${ }^{1 *}$ and Pradeep S. Anand ${ }^{2}$ \\ ${ }^{1}$ Department of Preventive Dental Sciences, College of Dentistry, Prince Sattam Bin Abdulaziz University, Al-Kharj, \\ Saudi Arabia, ${ }^{2}$ Department of Dentistry, ESIC Medical College, Parippally, India
}

Early childhood caries (ECC) is major oral health problem, mainly in socially disadvantaged populations. ECC affects infants and preschool children worldwide. The prevalence of ECC differs according to the group examined, and a prevalence of up to $85 \%$ has been reported for disadvantaged groups. ECC is the presence of one or more decayed, missing, or filled primary teeth in children aged 71 months (5 years) or younger. It begins with white-spot lesions in the upper primary incisors along the margin of the gingiva. If the disease continues, caries can progress, leading to complete destruction of the crown. The main risk factors in the development of ECC can be categorized as microbiological, dietary, and environmental risk factors. Even though it is largely a

OPEN ACCESS

Edited by:

Seter Siziya,

Copperbelt University, Zambia

Reviewed by:

Alla B. Salmina,

Krasnoyarsk State Medical University named after Prof. V.F. Voino-

Yasenetsky, Russia

Agima Ljaljević,

Center of Health Promotion Institute of Public Health, Montenegro

${ }^{*}$ Correspondence:

Sukumaran Anil

drsanil@gmail.com

Specialty section:

This article was submitted to Child Health and Human Development,

a section of the journal

Frontiers in Pediatrics

Received: 28 March 2017

Accepted: 27 June 2017

Published: 18 July 2017

Citation:

Anil S and Anand PS (2017) Early Childhood Caries: Prevalence, Risk Factors, and Prevention.

Front. Pediatr. 5:157.

doi: 10.3389/fped.2017.00157 preventable condition, ECC remains one of the most common childhood diseases. The major contributing factors for the for the high prevalence of ECC are improper feeding practices, familial socioeconomic background, lack of parental education, and lack of access to dental care. Oral health plays an important role in children to maintain the oral functions and is required for eating, speech development, and a positive self-image. The review will focus on the prevalence, risk factors, and preventive strategies and the management of ECC.

Keywords: dental caries, early childhood caries, dietary habits, oral health, pediatric oral health, sociodemographic factors, infant feeding

\section{INTRODUCTION}

Early childhood caries (ECC) has been on the increase in many countries and has become a significant health problem especially in socially disadvantaged populations. ECC is defined as the presence of one or more decayed, missing, or filled tooth surfaces in any primary tooth in a child at 71 months of age or younger. It has several unique characteristics in clinical appearance such as rapid development of caries, which affects a number of teeth soon after they emerge in oral cavity. These lesions involve tooth surfaces that are less prone to caries development. Several terminologies were used to describe the condition such as, nursing bottle caries, nursing caries, rampant caries, baby bottle caries, baby bottle tooth decay, milk bottle syndrome, and prolonged nursing habit caries. ECC is a multifactorial disease that results from the interaction of factors that include cariogenic microorganisms, exposure to fermentable carbohydrates through inappropriate feeding practices, and a range of social variables. ECC is a severe health condition found among children living in socially disadvantaged communities in which malnutrition is a social and health disparity $(1,2)$. ECC is associated with other health problems, ranging from local pain, infections, abscesses, leading to difficulty in chewing, malnutrition, gastrointestinal disorders, and difficulty in sleeping (3). 
The etiology of ECC is multifactorial and is mainly attributed to a time-specific interaction of microorganisms with sugars on a tooth surface (Figure 1) (4). Diet and feeding practices also play an important role in acquisition of the infection and development of caries $(5,6)$. Factors such as high sugar intake, lack of oral hygiene, lack of fluoride exposure, and enamel defects are some of the major factors responsible for the development of ECC (7-9). ECC is higher among the more socially disadvantaged and particularly for children who are refugees or migrants, or whose parents are refugees or migrants from third world countries (10, 11). This could be related to low socioeconomic status, social exclusion, and sociocultural differences in oral health beliefs and practices (12). ECC is a serious oral health problem, especially in disadvantaged communities in both developing and industrialized countries in which undernutrition is very common (13).

\section{EPIDEMIOLOGY OF ECC}

Despite the decline in the prevalence of dental caries in children in western countries, caries in preschool children remains a major problem in both developed and developing countries (13). Prevalence of ECC also varies widely with several factors like race, culture, and ethnicity; socioeconomic status, life style, dietary pattern, and oral hygiene practices and also according to the various factors from country to country and from area to area. A review of the literature suggests that in most developed countries the prevalence rate of ECC is between 1 and 12\% (14). In less developed countries and among the disadvantaged groups in the developed countries, the prevalence has been reported to be as high as $70 \%$. ECC has been found to be more prevalent in low socioeconomic groups $(15,16)$. The prevalence ranged from $11.4 \%$ in Sweden to $7-19.0 \%$ in Italy $(17,18)$. A high prevalence of ECC has been reported in some Middle Eastern countries, such as Palestine (76\%) and the United Arab Emirates (83\%) $(19,20)$. The national surveys from some countries, such as Greece (36\%), Brazil (45.8\%), India (51.9\%), and Israel (64.7\%), showed inconsistent prevalence of ECC (21-24). In a systematic review, Ismail and Sohn (25) found that the prevalence varied from $2.1 \%$ in Sweden to $85.5 \%$ in rural Chinese children. The national prevalence of ECC in the USA can be estimated between 3 and $6 \%$, which is consistent with the prevalence in other western countries $(26,27)$. According to a study, the highest prevalence of ECC is found in the 3- to 4-year-old age group and that boys are significantly more affected than girls, aged between 8 months and 7 years (28). Epidemiological studies from Europe showed significant percentages of the preschool children are affected by ECC, confirming the widespread prevalence of the disease. ECC is randomly dispersed in the population, with the disease affecting disproportionately among deprived families (29).

\section{ETIOLOGY OF ECC}

Dental caries results from the interaction of various etiological factors, which might be concurrently present to initiate and progress the disease. The factors are (1) cariogenic microorganisms, (2) fermentable carbohydrates (substrate), and (3) susceptible tooth surface/host. There are a multitude of risk factors associated with ECC. Epidemiological studies have also documented low socioeconomic status, minority status, low birth weight, and transfer of microbes from mother to child. One to twelve

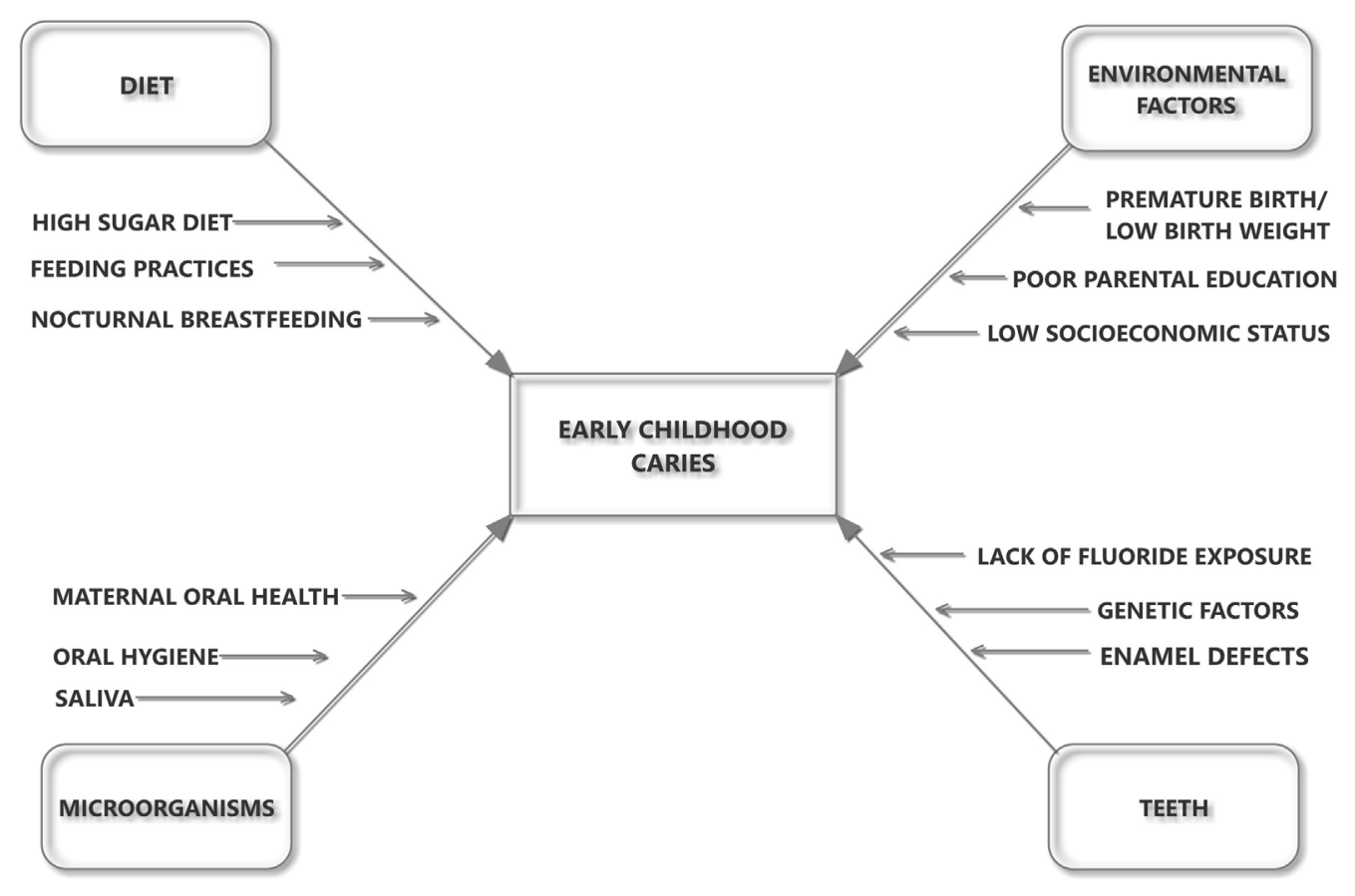

FIGURE 1 | The influence of host-microbe-diet interactions in the etiology and pathogenesis of early childhood caries. 
percent of children younger than 6 years in the developed world experience ECC $(30,31)$. Child oral health-care behavior, feeding and cleaning behavior are associated with ECC among children; night time bottle feeding and frequent consumption of cariogenic food; late commencement of child tooth brushing and irregular brushing habits (32-34).

\section{Cariogenic Microorganisms}

Streptococcus mutans (SM) and Streptococcus sobrinus are the most common microorganisms associated with ECC. Lactobacilli also participate in the development of caries lesions and play an important role in lesion progression, but not its initiation (35). SM metabolizes sugars to produce acids, which contribute to the demineralization of tooth structure (36). These bacteria can be transmitted from mother to child (37). Preschool children with high levels of SM in the oral cavity had higher caries prevalence and a greater risk for development of new lesions (38). Milgrom et al. (9) found that children having a high SM levels were five times more prone to have dental caries. The major source of acquiring the SM is from the mother during first 12-24 months. Poor maternal oral hygiene maintenance and frequent snacking and sugar exposure increase the chances of transmission of the infection to child (39). SM isolates from infants indicated that the source of the SM in children is mainly from their mothers via vertical transmission through saliva $(40,41)$. Horizontal transmission of microbes may occur between siblings and care givers $(42,43)$. Infants delivered by cesarean section acquire SM earlier than vaginally delivered infants since these deliveries are more aseptic and the atypical microbial environment increases the chances of SM colonization (44). The Actinomyces species and specifically Actinomyces gerencseriae were also associated with caries initiation (45), while Bifidobacterium species was associated with deep caries lesions (46). Few non-mutans streptococci that have acidogenic and aciduric properties were also associated with caries $(47,48)$. Epidemiological data suggest that Candida albicans also plays an active role in the pathogenesis of dental caries $(49,50)$. SM is the main bacteria that have strong association to dental caries whereas the other oral bacteria in the dental plaque could be involved in the initiation and progression of caries.

\section{Diet}

Dietary practices also play a significant role in the development of ECC especially if it contains high levels of fermentable carbohydrates; the child is at higher risk for dental caries (51). Inappropriate feeding practice can prolong the exposure of teeth to fermentable carbohydrates which in turn may aggravate the chances of ECC. Bottle feeding during bedtime or sleeping has been associated with the initiation and development of caries in children (52). SM converts fermentable carbohydrates into acids, which can demineralize enamel and dentin (53). Studies have shown that cow milk has minimal cariogenicity due to its mineral content and low lactose level (54-56). Iida et al. (57) showed that breast feeding and its duration were independently associated with an increased risk for ECC among 2- to 5-year-old children. A systematic review revealed that breast feeding for more than a year and at night might be associated with an increased prevalence of dental caries (58). Infant feeding practices such as frequent exposure to sugar, frequent snacking, taking sweetened drinks to bed, sharing foods with adults, as well as maternal caries status, oral hygiene and dietary habits predispose to early SM colonization and establishment of high MS counts (51).

\section{Environmental Factors}

Lack of good oral hygiene practices promotes the development of ECC. Children should begin receiving oral hygiene care upon the eruption of the first primary tooth (59). Children from low socioeconomic status are two times more likely to have dental caries than from higher income strata (60). Caregivers' social status, poverty, ethnicity, deprivation, number of years of education, and dental insurance coverage are other factors which influence the oral hygiene habits of children and the severity of $\operatorname{ECC}(28,61)$.

Saliva has a protective role against dental caries development by providing the main defense system. Saliva flow rate, antimicrobial properties, the buffering capacity, and clearance of foods from the oral cavity are factors that are important in reducing the development of caries (62). Feeding of high sugar containing food at night may increase the caries risk for infants and toddlers due to the low salivary flow rate (63). Studies have shown the presence of enamel hypoplastic defects with prenatal conditions such as premature birth and low birth weight, as well as with malnutrition and illness $(64,65)$. In a case-control study, enamel hypoplasia was reported in $67 \%$ of low birth weight children in comparison to $10 \%$ among normal birth weight children (66). Although enamel hypoplasia has been confirmed as an independent risk factor for caries, the causal relationship with dental caries has not been established. Low socioeconomic status, poor parental education, and life style factors have significant influence on ECC (67). Leroy et al. (68) reported a significant relationship between parental smoking habit and caries experience children.

\section{CLINICAL PRESENTATION}

ECC is a form of early, moderate and late dental decay that affects the primary teeth of infants and toddlers. It develops on tooth surfaces that are usually at low risk for caries, such as the labial surfaces of maxillary incisors and lingual and buccal surfaces of maxillary and mandibular molars. ECC initially presents as dull white or brown spots on maxillary incisors along the gingival margin, which progresses to a complete destruction of the crown, leading to root stumps (1). In moderate stage, the caries begins to spread to the maxillary molars. In the severe stage, the caries process destroys the maxillary teeth and spreads to the mandibular molars. Based on the clinical appearance, attempts were made to classify the ECC (27). Severe early childhood caries (S-ECC) refers to children with 'atypical,' 'progressive,' 'acute,' or 'rampant' pattern of dental caries $(25,69)$. A child with ECC may suffer from considerable pain, which may lead to difficulty in eating and talking (70). If the extent of the damage results in extraction of the anterior teeth by age 2 or 3 years, the child may suffer further developmental delays involving speech articulation and patterns (71). The consequences are delay in physical development due to poor nutrition and the pain and discomfort may compromise 
their desire to eat. The pain and suffering associated with the caries affect the child's oral health quality of life (72).

\section{CLASSIFICATION}

Several research groups have attempted to develop classification systems for early childhood caries (Tables 1-3).

Another classification based on the stage of development of the dentition and severity of dental caries (initial and cavitated) was proposed by Veerkamp and Weerheijm (74). This system assumes that dental caries occurs in successive stages starting late in the first year (10 months) and ending in the fourth year of life (48 months). The four stages were referred to as: initial, damaged, deep lesions, and traumatic. During each stage, a different group of teeth are involved, and dental caries can range from enamel demineralization (opaque white demineralization) to cavitation involving enamel and dentine.

TABLE 1 | Classification based on the severity of ECC and etiology (73).
Type I (mild to moderate)

Type II (moderate to severe)

Type III (severe)
The existence of 'isolated carious lesion(s)' involving incisors and/or molars. The most common causes are usually a combination of semisolid or solid food and lack of oral hygiene.

ECC was described as 'labiolingual lesions' affecting maxillary incisors, with or without molar caries, depending on the age of the child and stage of the disease. Typically, the mandibular incisors are unaffected. The cause is usually inappropriate use of a feeding bottle or at-will breast-feeding or a combination of both, with or without poor oral hygiene.

ECC was described as carious lesions affecting almost all teeth including the mandibular incisors. A combination of cariogenic food substances and poor oral hygiene is the cause of this type of ECC.
TABLE 2 | Classification based on the pattern of ECC presentation (27).

Type 1 Lesions associated with developmental defects (pit and fissure defects and hypoplasia)

Type 2 Smooth surface lesions (labial-lingual lesions, approximal molar lesions)

Type 3 Rampant caries - having caries in 14 out of 20 primary teeth, including at least one mandibular incisor

TABLE 3 | Classification of ECC and Severe Early Childhood Caries (S-ECC) $(1,69)$.

Age (months) Early childhood Severe early childhood caries caries

\begin{tabular}{|c|c|c|}
\hline$<12$ & $\begin{array}{l}1 \text { or more dmfs } \\
\text { surfaces }\end{array}$ & 1 or more smooth dmf surfaces. \\
\hline $12-23$ & $\begin{array}{l}1 \text { or more dmfs } \\
\text { surfaces }\end{array}$ & 1 or more smooth dmf surfaces. \\
\hline $24-35$ & $\begin{array}{l}1 \text { or more dmfs } \\
\text { surfaces }\end{array}$ & 1 or more smooth dmf surfaces. \\
\hline $36-47$ & $\begin{array}{l}1 \text { or more dmfs } \\
\text { surfaces }\end{array}$ & $\begin{array}{l}1 \text { or more cavitated, filled, or missing (due to } \\
\text { caries) smooth surfaces in primary maxillary } \\
\text { anterior teeth or dmfs score }>4 \text {. }\end{array}$ \\
\hline $48-59$ & $\begin{array}{l}1 \text { or more dmfs } \\
\text { surfaces }\end{array}$ & $\begin{array}{l}1 \text { or more cavitated, filled, or missing (due } \\
\text { to caries) smooth surfaces in primary } \\
\text { maxillary anterior teeth or dmfs score }>5 \text {. }\end{array}$ \\
\hline
\end{tabular}

\section{MANAGEMENT}

Maintaining primary dentition in a healthy condition is important for the well-being of the child. Primary dentition is required for proper mastication, esthetics, phonetics, space maintenance, and for prevention of aberrant habits. Reducing dental plaque formation, changing the bacterial composition of plaque, and modification of dietary habits are essential for the prevention of dental caries. Prevention of the progress of the ECC can be achieved with the aid of restorations, diet counseling, educating parents regarding decay promoting feeding behaviors, maintain good oral hygiene, and the use of preventive agents like topical fluorides (75). The management of ECC is expensive, often requiring extensive restorative treatment and extraction of teeth at an early age. General anesthesia or deep sedation may be required at times, since young children lack the ability to cope with the extensive treatment procedures (76). Chemotherapeutic agents, such as povidone-iodine and chlorhexidine, have shown antimicrobial effect against the most cariogenic SM $(77,78)$. Chlorhexidine varnish is applied to protect the tooth surface (79).

In addition, fluorides are very effective in preventing dental caries, including fluoride toothpaste, water fluoridation, fluoride mouth rinse, and professional topical fluoride application, primarily by inhibiting mineral loss from the tooth. Tooth paste containing fluoride showed a strong preventive effect in young permanent teeth (80). Professionally applied fluoride varnishes and supervised use of fluoride mouth rinses also showed reduction in childhood caries $(81,82)$. The application of casein phosphor peptide (CPP) could stabilize the calcium and phosphate thereby preserving them in an amorphous or soluble form known as amorphous calcium phosphate (ACP). Calcium and phosphate are essential components of enamel and dentine and form highly insoluble complexes in the presence of CPP. CPP-ACP complexes can prevent tooth demineralization and improve enamel remineralization and enhance fluoride activity. Hence, the application of CPP-ACP-based compounds helps in the prevention of dental caries $(83,84)$.

\section{Preventive Measures}

Early childhood caries preventive strategies should begin with prenatal education of expectant parent(s), progress through the perinatal period, and continue with the mother and infant (Figure 2). Adequate dental treatment and oral hygiene measures during pregnancy can reduce or delay ECC in infants (85). Parents also should be advised to maintain optimal dental health during pre- and postnatal periods $(86,87)$. Measures should be taken in educating parent/caregiver about the etiology and prevention of ECC (88). Nurses are also in a position to carry out prevention efforts for infants, toddlers, and their families and can provide counseling and support for children who suffer from ECC (86). A recently published multilevel conceptual model, incorporating influences of ECC exerted at the individual, family, and community level suggests that both social and behavioral change is important in the prevention of this oral disease (89). Use of probiotics chewable tables or 


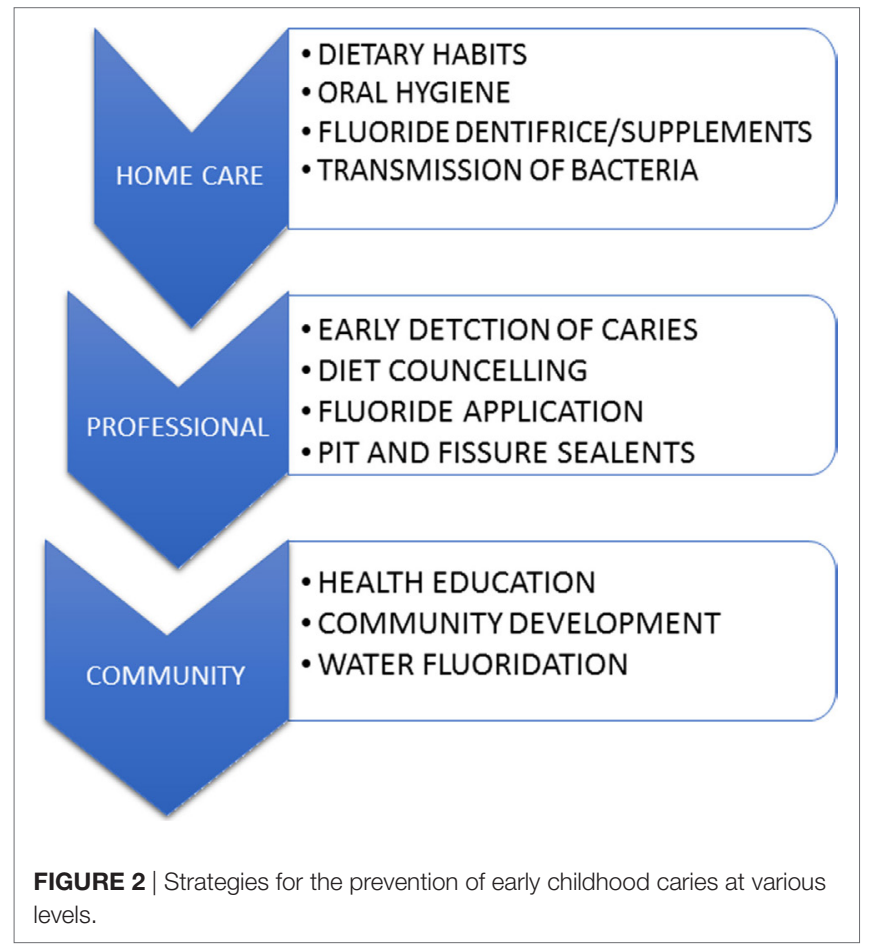

supplements also showed some evidence in controlling the caries in children. However, its effectiveness to prevent ECC is still under investigation $(90,91)$.

\section{REFERENCES}

1. De Grauwe A, Aps JK, Martens LC. Early childhood caries (ECC): what's in a name? Eur J Paediatr Dent (2004) 5(2):62-70.

2. Feldens CA, Giugliani ER, Duncan BB, Drachler Mde L, Vitolo MR. Long-term effectiveness of a nutritional program in reducing early childhood caries: a randomized trial. Community Dent Oral Epidemiol (2010) 38(4):324-32. doi:10.1111/j.1600-0528.2010.00540.x

3. Finlayson TL, Siefert K, Ismail AI, Sohn W. Psychosocial factors and early childhood caries among low-income African-American children in Detroit. Community Dent Oral Epidemiol (2007) 35(6):439-48. doi:10.1111/ j.1600-0528.2006.00352.x

4. Nunn ME, Braunstein NS, Krall Kaye EA, Dietrich T, Garcia RI, Henshaw MM. Healthy eating index is a predictor of early childhood caries. J Dent Res (2009) 88(4):361-6. doi:10.1177/0022034509334043

5. Berkowitz RJ. Causes, treatment and prevention of early childhood caries: a microbiologic perspective. J Can Dent Assoc (2003) 69(5):304-7.

6. Palmer CA, Kent R Jr, Loo CY, Hughes CV, Stutius E, Pradhan N, et al. Diet and caries-associated bacteria in severe early childhood caries. J Dent Res (2010) 89(11):1224-9. doi:10.1177/0022034510376543

7. Harris R, Nicoll AD, Adair PM, Pine CM. Risk factors for dental caries in young children: a systematic review of the literature. Community Dent Health (2004) 21(1 Suppl):71-85.

8. Uribe S. Early childhood caries - risk factors. Evid Based Dent (2009) 10(2):37-8. doi:10.1038/sj.ebd.6400642

9. Milgrom P, Riedy CA, Weinstein P, Tanner AC, Manibusan L, Bruss J. Dental caries and its relationship to bacterial infection, hypoplasia, diet, and oral hygiene in 6- to 36-month-old children. Community Dent Oral Epidemiol (2000) 28(4):295-306. doi:10.1034/j.1600-0528.2000.280408.x

10. Watt RG. From victim blaming to upstream action: tackling the social determinants of oral health inequalities. Community Dent Oral Epidemiol (2007) 35(1):1-11. doi:10.1111/j.1600-0528.2007.00348.x

\section{CONCLUSION}

ECC is a chronic, infectious disease affecting young children, and constitutes a serious public health problem. It is one of the most common preventable diseases and is on the rise worldwide. ECC is a multifactorial disease consequent to the interaction of cariogenic microorganisms, exposure to carbohydrates, inappropriate feeding practices, and a range of social variables. It can affect a child's well-being, learning ability, and quality of life. This virulent form of dental caries begins soon after dental eruption mainly on the smooth surfaces of the teeth, which progress at a rapid state. It has a lasting detrimental impact on the dentition. The associated pain from dental caries has a negative impact on children's emotional status, sleep patterns, and ability to learn or perform their usual activities. A wide range of risk factors are associated with ECC in children from underprivileged and low socioeconomic status. Oral health has been recognized as an essential component of general health and quality of life. Hence both oral disease prevention and oral health promotion should be included as an integral part of chronic disease prevention and general health promotion programs.

\section{AUTHOR CONTRIBUTIONS}

SA and PA contributed in the concept, design of the review drafting, and revising the manuscript.

11. Edelstein BL. The dental caries pandemic and disparities problem. BMC Oral Health (2006) 6(Suppl 1):S2. doi:10.1186/1472-6831-6-s1-s2

12. Edelstein BL. Solving the problem of early childhood caries: a challenge for us all. Arch Pediatr Adolesc Med (2009) 163(7):667-8. doi:10.1001/ archpediatrics.2009.107

13. Masumo R, Bardsen A, Mashoto K, Astrom AN. Prevalence and sociobehavioral influence of early childhood caries, ECC, and feeding habits among 6-36 months old children in Uganda and Tanzania. BMC Oral Health (2012) 12:24. doi:10.1186/1472-6831-12-24

14. Congiu G, Campus G, Luglie PF. Early childhood caries (ECC) prevalence and background factors: a review. Oral Health Prev Dent (2014) 12(1):71-6. doi:10.3290/j.ohpd.a31216

15. Ismail AI, Lim S, Sohn W, Willem JM. Determinants of early childhood caries in low-income African American young children. Pediatr Dent (2008) 30(4):289-96.

16. Vachirarojpisan T, Shinada K, Kawaguchi Y, Laungwechakan P, Somkote T, Detsomboonrat P. Early childhood caries in children aged 6-19 months. Community Dent Oral Epidemiol (2004) 32(2):133-42. doi:10.1111/j.03015661.2004.00145.x

17. Stromberg U, Holmn A, Magnusson K, Twetman S. Geo-mapping of time trends in childhood caries risk - a method for assessment of preventive care. BMC Oral Health (2012) 12:9. doi:10.1186/1472-6831-12-9

18. Nobile CG, Fortunato L, Bianco A, Pileggi C, Pavia M. Pattern and severity of early childhood caries in Southern Italy: a preschool-based crosssectional study. BMC Public Health (2014) 14:206. doi:10.1186/1471-245814-206

19. Azizi Z. The prevalence of dental caries in primary dentition in 4 - to 5 -year-old preschool children in northern Palestine. Int J Dent (2014) 2014:839419. doi:10.1155/2014/839419

20. El-Nadeef MA, Hassab H, Al-Hosani E. National survey of the oral health of 5-year-old children in the United Arab Emirates. East Mediterr Health J (2010) 16(1):51-5. 
21. Oulis CJ, Tsinidou K, Vadiakas G, Mamai-Homata E, Polychronopoulou A, Athanasouli T. Caries prevalence of 5,12 and 15-year-old Greek children: a national pathfinder survey. Community Dent Health (2012) 29(1): 29-32.

22. Gomes PR, Costa SC, Cypriano S, de Sousa Mda L. [Dental caries in Paulinia, Sao Paulo State, Brazil, and WHO goals for 2000 and 2010]. Cad Saude Publica (2004) 20(3):866-70. doi:10.1590/S0102-311X2004000300024

23. Koya S, Ravichandra KS, Arunkumar VA, Sahana S, Pushpalatha HM. Prevalence of early childhood caries in children of West Godavari District, Andhra Pradesh, South India: an epidemiological study. Int J Clin Pediatr Dent (2016) 9(3):251-5. doi:10.5005/jp-journals-10005-1372

24. Natapov L, Gordon M, Pikovsky V, Kushnir D, Kooby E, Khoury G, et al. Caries prevalence among five-year-old children examined by the school dental service in Israel in 2007. Oral Health Dent Manag (2010) 9:25-31.

25. Ismail AI, Sohn W. A systematic review of clinical diagnostic criteria of early childhood caries. J Public Health Dent (1999) 59(3):171-91. doi:10.1111/ j.1752-7325.1999.tb03267.x

26. Horowitz HS. Research issues in early childhood caries. Community Dent Oral Epidemiol (1998) 26(1 Suppl):67-81. doi:10.1111/j.1600-0528.1998. tb02099.x

27. Johnston T, Messer LB. Nursing caries: literature review and report of a case managed under local anaesthesia. Aust Dent J (1994) 39(6):373-81. doi:10.1111/j.1834-7819.1994.tb03110.x

28. Ramos-Gomez FJ, Weintraub JA, Gansky SA, Hoover CI, Featherstone JD. Bacterial, behavioral and environmental factors associated with early childhood caries. JClin Pediatr Dent (2002) 26(2):165-73. doi:10.17796/jcpd. 26.2.t6601j3618675326

29. Vadiakas G. Case definition, aetiology and risk assessment of early childhood caries (ECC): a revisited review. Eur Arch Paediatr Dent (2008) 9(3):114-25. doi:10.1007/BF03262622

30. Barnes GP, Parker WA, Lyon TC Jr, Drum MA, Coleman GC. Ethnicity, location, age, and fluoridation factors in baby bottle tooth decay and caries prevalence of Head Start children. Public Health Rep (1992) 107(2):167-73.

31. Bernabe E, MacRitchie H, Longbottom C, Pitts NB, Sabbah W. Birth weight, breastfeeding, maternal smoking and caries trajectories. J Dent Res (2017) 96(2):171-8. doi:10.1177/0022034516678181

32. Senesombath S, Nakornchai S, Banditsing P, Lexomboon D. Early childhood caries and related factors in Vientiane, Lao PDR. Southeast Asian J Trop Med Public Health (2010) 41(3):717-25.

33. Slabsinskiene E, Milciuviene S, Narbutaite J, Vasiliauskiene I, Andruskeviciene V, Bendoraitiene EA, et al. Severe early childhood caries and behavioral risk factors among 3-year-old children in Lithuania. Medicina (Kaunas) (2010) 46(2):135-41.

34. Gordon N. Oral health care for children attending a malnutrition clinic in South Africa. Int J Dent Hyg (2007) 5(3):180-6. doi:10.1111/j.1601-5037.2007. 00261.x

35. Kawashita Y, Kitamura M, Saito T. Early childhood caries. Int J Dent (2011) 2011:725320. doi:10.1155/2011/725320

36. Zero DT, Fu J, Anne KM, Cassata S, McCormack SM, Gwinner LM. An improved intra-oral enamel demineralization test model for the study of dental caries. J Dent Res (1992) 71:871-8.

37. Mitchell SC, Ruby JD, Moser S, Momeni S, Smith A, Osgood R, et al. Maternal transmission of mutans Streptococci in severe-early childhood caries. Pediatr Dent (2009) 31(3):193-201.

38. O'Sullivan DM, Thibodeau EA. Caries experience and mutans streptococci as indicators of caries incidence. Pediatr Dent (1996) 18(5):371-4.

39. Berkowitz RJ. Mutans streptococci: acquisition and transmission. Pediatr Dent (2006) 28(2):106-9.

40. Mattos-Graner RO, Li Y, Caufield PW, Duncan M, Smith DJ. Genotypic diversity of mutans streptococci in Brazilian nursery children suggests horizontal transmission. J Clin Microbiol (2001) 39(6):2313-6. doi:10.1128/jcm. 39.6.2313-2316.2001

41. Klein MI, Florio FM, Pereira AC, Hofling JF, Goncalves RB. Longitudinal study of transmission, diversity, and stability of Streptococcus mutans and Streptococcus sobrinus genotypes in Brazilian nursery children. J Clin Microbiol (2004) 42(10):4620-6. doi:10.1128/jcm.42.10.4620-4626.2004

42. Wan AK, Seow WK, Purdie DM, Bird PS, Walsh LJ, Tudehope DI. A longitudinal study of Streptococcus mutans colonization in infants after tooth eruption. J Dent Res (2003) 82(7):504-8. doi:10.1177/154405910308200703
43. Kozai K, Nakayama R, Tedjosasongko U, Kuwahara S, Suzuki J, Okada M, et al. Intrafamilial distribution of mutans streptococci in Japanese families and possibility of father-to-child transmission. Microbiol Immunol (1999) 43(2):99-106. doi:10.1111/j.1348-0421.1999.tb02380.x

44. Li Y, Caufield PW, Dasanayake AP, Wiener HW, Vermund SH. Mode of delivery and other maternal factors influence the acquisition of Streptococcus mutans in infants. J Dent Res (2005) 84(9):806-11. doi:10.1177/ 154405910508400905

45. Becker MR, Paster BJ, Leys EJ, Moeschberger ML, Kenyon SG, Galvin JL, et al. Molecular analysis of bacterial species associated with childhood caries. JClin Microbiol (2002) 40(3):1001-9. doi:10.1128/JCM.40.3.10011009.2002

46. van Houte J, Lopman J, Kent $\mathrm{R}$. The final $\mathrm{pH}$ of bacteria comprising the predominant flora on sound and carious human root and enamel surfaces. J Dent Res (1996) 75(4):1008-14. doi:10.1177/00220345960750040201

47. van Ruyven FO, Lingstrom P, van Houte J, Kent R. Relationship among mutans streptococci, "low-pH" bacteria, and lodophilic polysaccharide-producing bacteria in dental plaque and early enamel caries in humans. J Dent Res (2000) 79(2):778-84. doi:10.1177/00220345000790021201

48. Lingstrom P, van Ruyven FO, van Houte J, Kent R. The $\mathrm{pH}$ of dental plaque in its relation to early enamel caries and dental plaque flora in humans. J Dent Res (2000) 79(2):770-7. doi:10.1177/00220345000790021101

49. Yang XQ, Zhang Q, Lu LY, Yang R, Liu Y, Zou J. Genotypic distribution of Candida albicans in dental biofilm of Chinese children associated with severe early childhood caries. Arch Oral Biol (2012) 57(8):1048-53. doi:10.1016/j. archoralbio.2012.05.012

50. de Carvalho FG, Silva DS, Hebling J, Spolidorio LC, Spolidorio DM. Presence of mutans streptococci and Candida spp. in dental plaque/dentine of carious teeth and early childhood caries. Arch Oral Biol (2006) 51(11):1024-8. doi:10.1016/j.archoralbio.2006.06.001

51. Paglia L, Scaglioni S, Torchia V, De Cosmi V, Moretti M, Marzo G, et al. Familial and dietary risk factors in early childhood caries. Eur J Paediatr Dent (2016) 17(2):93-9.

52. Twetman S, Garcia-Godoy F, Goepferd SJ. Infant oral health. Dent Clin North Am (2000) 44(3):487-505.

53. Loesche WJ. Role of Streptococcus mutans in human dental decay. Microbiol $\operatorname{Rev}(1986)$ 50(4):353-80.

54. Bowen WH, Pearson SK, VanWuyckhuyse BC, Tabak LA. Influence of milk, lactose-reduced milk, and lactose on caries in desalivated rats. Caries Res (1991) 25(4):283-6. doi:10.1159/000261377

55. Marshall TA, Levy SM, Broffitt B, Warren JJ, Eichenberger-Gilmore JM, Burns TL, et al. Dental caries and beverage consumption in young children. Pediatrics (2003) 112(3 Pt 1):e184-91. doi:10.1542/peds.112.3.e184

56. Bowen WH, Lawrence RA. Comparison of the cariogenicity of cola, honey, cow milk, human milk, and sucrose. Pediatrics (2005) 116(4):921-6. doi:10.1542/peds.2004-2462

57. Iida $\mathrm{H}$, Auinger $\mathrm{P}$, Billings RJ, Weitzman M. Association between infant breastfeeding and early childhood caries in the United States. Pediatrics (2007) 120(4):e944-52. doi:10.1542/peds.2006-0124

58. Valaitis R, Hesch R, Passarelli C, Sheehan D, Sinton J. A systematic review of the relationship between breastfeeding and early childhood caries. Can J Public Health (2000) 91(6):411-7.

59. Olmez S, Uzamis M, Erdem G. Association between early childhood caries and clinical, microbiological, oral hygiene and dietary variables in rural Turkish children. Turk J Pediatr (2003) 45(3):231-6.

60. Gaur S, Nayak R. Underweight in low socioeconomic status preschool children with severe early childhood caries. J Indian Soc Pedod Prev Dent (2011) 29(4):305-9. doi:10.4103/0970-4388.86375

61. Aida J, Ando Y, Aoyama H, Tango T, Morita M. An ecological study on the association of public dental health activities and sociodemographic characteristics with caries prevalence in Japanese 3-year-old children. Caries Res (2006) 40(6):466-72. doi:10.1159/000095644

62. Jiang S, Gao X, Jin L, Lo EC. Salivary microbiome diversity in caries-free and caries-affected children. Int J Mol Sci (2016) 17(12):E1978. doi:10.3390/ ijms 17121978

63. Silva PV, Troiano JA, Nakamune AC, Pessan JP, Antoniali C. Increased activity of the antioxidants systems modulate the oxidative stress in saliva of toddlers with early childhood caries. Arch Oral Biol (2016) 70:62-6. doi:10.1016/j. archoralbio.2016.06.003 
64. Pitiphat W, Luangchaichaweng S, Pungchanchaikul P, Angwaravong O, Chansamak N. Factors associated with molar incisor hypomineralization in Thai children. Eur JOral Sci (2014) 122(4):265-70. doi:10.1111/eos. 12136

65. Prokocimer T, Amir E, Blumer S, Peretz B. Birth-weight, pregnancy term, pre-natal and natal complications related to child's dental anomalies. J Clin Pediatr Dent (2015) 39(4):371-6. doi:10.17796/1053-4628-39.4.371

66. Lai PY, Seow WK, Tudehope DI, Rogers Y. Enamel hypoplasia and dental caries in very-low birthweight children: a case-controlled, longitudinal study. Pediatr Dent (1997) 19(1):42-9.

67. Dabawala S, Suprabha BS, Shenoy R, Rao A, Shah N. Parenting style and oral health practices in early childhood caries: a case-control study. Int J Paediatr Dent (2017) 27(2):135-44. doi:10.1111/ipd.12235

68. Leroy R, Hoppenbrouwers K, Jara A, Declerck D. Parental smoking behavior and caries experience in preschool children. Community Dent Oral Epidemiol (2008) 36(3):249-57. doi:10.1111/j.1600-0528.2007.00393.x

69. Drury TF, Horowitz AM, Ismail AI, Maertens MP, Rozier RG, Selwitz RH. Diagnosing and reporting early childhood caries for research purposes. A report of a workshop sponsored by the National Institute of Dental and Craniofacial Research, the Health Resources and Services Administration, and the Health Care Financing Administration. J Public Health Dent (1999) 59(3):192-7.

70. Barber LR, Wilkins EM. Evidence-based prevention, management, and monitoring of dental caries. J Dent Hyg (2002) 76(4):270-5.

71. Von Burg MM, Sanders BJ, Weddell JA. Baby bottle tooth decay: a concern for all mothers. Pediatr Nurs (1995) 21(6):515-9.

72. Li MY, Zhi QH, Zhou Y, Qiu RM, Lin HC. Impact of early childhood caries on oral health-related quality of life of preschool children. Eur J Paediatr Dent (2015) 16(1):65-72.

73. Wyne A. Prevalence and risk factors of nursing caries in Adelaide, South Australia. Pediatr Dent (1999) 9:31-6.

74. Veerkamp JS, Weerheijm KL. Nursing-bottle caries: the importance of a development perspective. ASDC J Dent Child (1995) 62(6):381-6.

75. Berkowitz RJ, Koo H, McDermott MP, Whelehan MT, Ragusa P, KopyckaKedzierawski DT, et al. Adjunctive chemotherapeutic suppression of mutans streptococci in the setting of severe early childhood caries: an exploratory study. J Public Health Dent (2009) 69(3):163-7. doi:10.1111/j.1752-7325.2009. 00118.x

76. Duangthip D, Jiang M, Chu CH, Lo EC. Restorative approaches to treat dentin caries in preschool children: systematic review. Eur J Paediatr Dent (2016) 17(2):113-21.

77. Amin MS, Harrison RL, Benton TS, Roberts M, Weinstein P. Effect of povidone-iodine on Streptococcus mutans in children with extensive dental caries. Pediatr Dent (2004) 26(1):5-10.

78. Jayaprakash R, Sharma A, Moses J. Comparative evaluation of the efficacy of different concentrations of chlorhexidine mouth rinses in reducing the mutans streptococci in saliva: an in vivo study. J Indian Soc Pedod Prev Dent (2010) 28(3):162-6. doi:10.4103/0970-4388.73792

79. Frentzen M, Ploenes K, Braun A. Clinical and microbiological effects of local chlorhexidine applications. Int Dent J (2002) 52(5):325-9. doi:10.1002/j. 1875-595X.2002.tb00879.x
80. Twetman S, Axelsson S, Dahlgren H, Holm AK, Kallestal C, Lagerlof F, et al. Caries-preventive effect of fluoride toothpaste: a systematic review. Acta Odontol Scand (2003) 61(6):347-55. doi:10.1080/00016350310007590

81. Marinho VC, Worthington HV, Walsh T, Clarkson JE. Fluoride varnishes for preventing dental caries in children and adolescents. Cochrane Database Syst Rev (2013) 11(7):Cd002279. doi:10.1002/14651858.CD002279. pub2

82. Marinho VC, Chong LY, Worthington HV, Walsh T. Fluoride mouthrinses for preventing dental caries in children and adolescents. Cochrane Database Syst Rev (2016) 11(7):Cd002284. doi:10.1002/14651858.CD002284. pub2

83. Pukallus ML, Plonka KA, Holcombe TF, Barnett AG, Walsh LJ, Seow WK. A randomized controlled trial of a 10 percent CPP-ACP cream to reduce mutans streptococci colonization. Pediatr Dent (2013) 35(7): 550-5.

84. Zhou C, Zhang D, Bai Y, Li S. Casein phosphopeptide-amorphous calcium phosphate remineralization of primary teeth early enamel lesions. J Dent (2014) 42(1):21-9. doi:10.1016/j.jdent.2013.11.005

85. Jackson JT, Quinonez RB, Kerns AK, Chuang A, Eidson RS, Boggess KA, et al. Implementing a prenatal oral health program through interprofessional collaboration. J Dent Educ (2015) 79(3):241-8.

86. Record S, Montgomery DF, Milano M. Fluoride supplementation and caries prevention. J Pediatr Health Care (2000) 14(5):247-9. doi:10.1067/ mph.2000.108756

87. Uribe S. Prevention and management of dental decay in the preschool child Aust Dent J (2006) 51(3):272-5. doi:10.1111/j.1834-7819.2006.tb00442.x

88. Lee GH, McGrath C, Yiu CK. Evaluating the impact of caries prevention and management by caries risk assessment guidelines on clinical practice in a dental teaching hospital. BMC Oral Health (2016) 16(1):58. doi:10.1186/ s12903-016-0217-9

89. Kim Seow W. Environmental, maternal, and child factors which contribute to early childhood caries: a unifying conceptual model. Int J Paediatr Dent (2012) 22(3):157-68. doi:10.1111/j.1365-263X.2011.01186.x

90. Hedayati-Hajikand T, Lundberg U, Eldh C, Twetman S. Effect of probiotic chewing tablets on early childhood caries - a randomized controlled trial. BMC Oral Health (2015) 15(1):112. doi:10.1186/s12903-015-0096-5

91. Jorgensen MR, Castiblanco G, Twetman S, Keller MK. Prevention of caries with probiotic bacteria during early childhood. Promising but inconsistent findings. Am J Dent (2016) 29(3):127-31.

Conflict of Interest Statement: The authors declare that the research was conducted in the absence of any commercial or financial relationships that could be construed as a potential conflict of interest.

Copyright (c) 2017 Anil and Anand. This is an open-access article distributed under the terms of the Creative Commons Attribution License (CC BY). The use, distribution or reproduction in other forums is permitted, provided the original author(s) or licensor are credited and that the original publication in this journal is cited, in accordance with accepted academic practice. No use, distribution or reproduction is permitted which does not comply with these terms. 